Journal of Property Research, 2010, Vol. 27 No 4, pp. 371-390

\title{
Is it worth identifying service employment (sub)centres when modelling apartment prices?
}

\section{Marko Kryvobokov}

Laboratory of Transport Economics (LET)

14, avenue Berthelot

F-69363 Lyon Cedex 07

France

E-mail: mark.kryvobokov@let.ish-lyon.cnrs.fr

Keywords: service employment centres, centrality, accessibility, apartment price, hedonic modelling 


\begin{abstract}
The use of the attributes of the central business district and several subcentres instead of the characteristics of all the land parcels or zones can be seen as a higher level of analysis in real estate valuation. However, old technological limitations on considering smaller territorial units are being successfully overcome. The question is whether or not we still need generalisation, i.e. to identify urban centres when modelling real estate prices, or whether it is preferable to operate at a lower spatial level. The application of the traditional approach of identifying centres is compared with an "objective" centrality index and a "subjective" accessibility index calculated for each zone. The purpose is to find out, which of the three concepts best fits a regression model of apartment prices and provides the best prediction. Both global and geographically weighted ordinary least squares regressions are used as well as spatial lag and spatial error models. We conclude that if a model is spatially weighted or the spatial effects are controlled, it is not that important which of the concepts is applied. Nevertheless, in most cases the highest predictive capacity is obtained with duocentric models.
\end{abstract}

Keywords: service employment centres, centrality, accessibility, apartment price, hedonic modelling

\title{
1. Introduction
}

The tradition to consider urban centres in different aspects of urban study is as old as urban modelling itself. Begun by von Thünen, it was strongly theoretically developed by Alonso and many others. With growth of secondary urban centres, Wingo, Wendt, Harris and Ullman and others shifted the focus from monocentric to polycentric models (e.g. Merlin, 1973; Harvey and Jowsey, 2004). Secondary centres (subcentres) are supposed to be sufficiently large to significantly influence the urban structure, including such crucial components as travel patterns and real estate values.

The use of the attributes of the central business district (CBD) and several subcentres instead of the characteristics of all land parcels/neighbourhoods/districts/zones can be seen as an attempt to achieve a higher level of analysis. In the real estate terms (Grissom and Diaz III, 1991) it corresponds to the transition from the second level of location (the relationship of a site to its surroundings) to the third level (the overall urban structure and the interrelationships of a community's land use pattern). In terms of urban geography (e.g. Sanders, 2007) it corresponds to a transition from a meso-geographical level to a macro-geographical 
level of a city. Thus, the identification of urban centres should be not an excessive simplification, but a reasonable generalisation of the description of reality.

With the rapid development in GIS and transportation analysis software, the old technological limitations on considering smaller territorial units are being successfully overcome, and research efforts can be directed to more detailed analyses, where, in principle, each land parcel in a city can be taken into account. Thus, we ask whether we still need generalisation, i.e. identifying urban centres, or whether we can operate with integral accessibility measures at meso- or even micro-geographical levels when modelling real estate prices. In the current study we address this question at the geographical level of Traffic Analysis Zones (TAZs). Our study was motivated by the existence of several important centres in Lyon that are difficult to identify formally and include in a hedonic price model. These difficulties stimulated us to apply alternative methods that avoid explicitly considering centres. The purpose of the paper is to find out, which of the three concepts: travel time to urban centres, an "objective" centrality index or a "subjective" accessibility index, best fits the hedonic model and provides the best prediction. In the hedonic modelling, we apply four approaches: global ordinary least squares (OLS), geographically weighted OLS, spatial lag, and spatial error.

Similarly to Sivitanidou (1996), instead of using employment centres in general, we focus on service employment centres. We wish to avoid a site without commercial services, but with a large industrial enterprise, being identified as a subcentre. Thus, we follow the suggestion of McDonald (2008) to consider employment density by industry sector.

The paper is organised as follows. Section 2 analyses the relevant studies from the urban economics, transport planning, and real estate valuation literature. The service employment centres in the Lyon Urban Area are identified in the Section 3 by applying residual analysis. Section 4, uses the other two approaches, namely the centrality index 
based on travel time as a result of transportation modelling, and the accessibility index based on a travel survey. Section 5 creates hedonic regression models of residential real estate prices, exploiting the identified service employment centres and the indices. Conclusions are then drawn.

\section{Literature review}

Theoretical models of formation of non-monocentric patterns developed in the urban economics literature during the last three decades include the studies by Fujita and Ogawa (1982), Fujita (1988), Anas and Kim (1996) and Fujita et al. (1997). In this paper the focus is on identifying existing subcentres and their influence on real estate prices, rather than on the formation of new subcentres.

Subjectivity in the identification of urban centres has been recognised and criticised (McDonald, 1987; McMillen and Lester, 2003). Several formal identification procedures have been developed. Thus, McDonald (1987) proposes identifying employment subcentres as secondary peaks in the gross employment density (employment divided by total land area) and the employment-population ratio. A peak means that all the adjacent zones outside a subcentre have a smaller density or ratio. Giuliano and Small (1991) and Small and Song (1994) apply a similar definition of a centre, which is a continuous set of zones, selected with cut-offs for density and total employment. In a more formal approach, employment density was found to be a function of the distance from the CBD as well as from subcentres. Applying a monocentric analysis of employment density, McDonald and Prather (1994) define subcentres as locations with significantly positive residuals. However, McMillen and McDonald (1994) noted that such an approach may overlook fairly large subcentres populated by firms with large internal scale economies because the employment effects may be highly localised. McMillen (2001) identified the potential subcentres as sites, which have statistically significant residuals of locally weighted regression of 
employment density on the distance from the CBD (the first stage). He then checked whether they provide significant explanatory power in a semiparametric employment density regression estimation (the second stage). McMillen (2001) applied the proposed procedure for six American metropolitan areas. McMillen and Smith (2003) applied this procedure to 62 large metropolitan areas in the USA. Craig and $\mathrm{Ng}$ (2001) used a nonparametric employment density function, namely quantile smoothing splines.

The CBD is usually the primary focus in hedonic price models. Although the $a$ priori CBD identification can be seen as a weak point, there are a few papers in the real estate domain where the CBD is not simply taken as the area usually referred to as the CBD. Söderberg and Janssen (1999) re-estimated their regression model changing the precise location of the CBD of Stockholm by a step of 50 metres; as a result, the best model of apartment prices has been obtained for a location one kilometre east of the place commonly viewed as the city centre. Sivitanidou (1996) used the McDonald (1987) definition of urban centres. At the same time, a formal approach to secondary centres in the real estate literature is rare. Among the relatively few examples are: McDonald and McMillen (1990), McMillen (1996) and Sivitanidou (1996).

As McMillen and Lester (2003) note, it is important to operate with an optimal number of subcentres. On the one hand, listing too many centre sites produces inefficient estimates and can influence other estimated coefficients when distance to a subcentre is highly correlated with other explanatory variables. On the other hand, incorrectly omitting subcentres causes other estimates to be biased. Ross et al. (2009) have highlighted the common inability to fit more than two distance variables arguing that two points in space triangulate the optimal position by fundamental geometry.

In the discussion above, the identification of urban centres and their accessibility measures as distance or travel time were addressed. However, the concept of accessibility is not limited to urban centres. Despite being the focus of research in 
transport planning for a long time (see Hansen, 1959; Morris et al., 1979), accessibility remains a rather illusive concept (Miller, 2008). As Morris et al. (1979) note, there is a critical distinction between the derivation of "objective" indicators of accessibility, and perceived measures. The former refers to location of opportunities and potential access to them (Morris et al., 1979; Krizek, 2005) and is related to the concept of centrality (Samaniego and Moses, 2008). The latter concerns realisation of this potential in terms of actual travel. In this respect Des Rosiers and Thériault (2008) define accessibility as the ease with which persons, living at a given location, can move to reach activities and services which they consider to be the most important. This, mostly behavioural and subjective, concept of accessibility is quite distinct from centrality which relies on structural features and relates to the proximity to urban amenities. These concepts of accessibility and centrality are exploited in the present paper.

Anas and Kim (1996) have analysed the urban economics studies which did not pre-specify any centres but used rent gradients and land use density peaks around the most accessible place(s) in urban space. Thériault et al. (2005) and Des Rosiers and Thériault (2008) have provided examples of hedonic modelling of real estate prices without explicitly considering the CBD and secondary centres, but with integral measures of centrality and accessibility. They found that the perceptual index of accessibility, based on interview and fuzzy logic criteria, far outweighs the centrality index in the hedonic model of housing prices in Quebec City.

\section{Identification of service employment centres}

The Lyon Urban Area ${ }^{1}$ (Figure 1) is the second largest by population in France. The data on population from INSEE $^{2}$ refer to $2005^{3}$. The central part of the area with a

\footnotetext{
${ }^{1}$ In this paper, three areas outside of the traditional boundaries of the Lyon Urban Area are also included. A considerable number of commuters reside in these more distant areas with local centres in Villefranchesur-Saône, Bourgoin-Jallieu, and Vienne.
} 
population of 613 thousand people consists of the cities of Lyon and Villeurbanne.

These cities, which have a common planning structure and transportation network are shown in Figure 1 (in white in the centre) divided by small zones and almost surrounded by other urbanised areas shown in dark grey. The population of these areas is 580 thousand inhabitants. The rest of the territory with 711 thousand inhabitants is less urbanised and is represented in light grey.

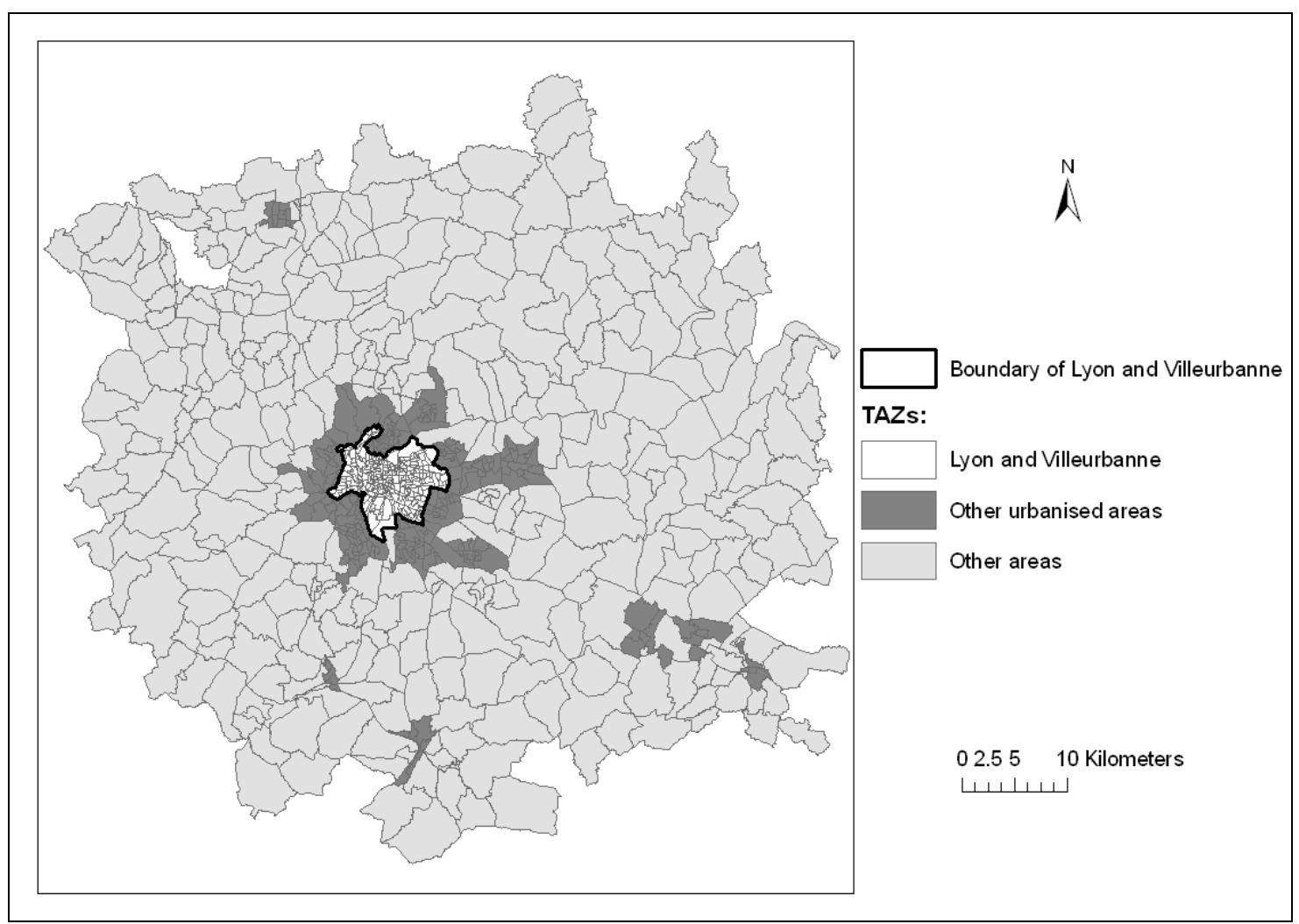

Figure 1. The Lyon Urban Area and surrounding areas

The historic centre of the city of Lyon, which was founded in the first century $\mathrm{BC}$, is located three kilometres to the North of the confluence of the Rhône and the Saône. Further development, in the medieval period and later, mainly occurred close to the historic centre, in the Peninsula (the area between the two rivers close to their confluence). Nowadays the Peninsula, which contains the city hall, other administrative buildings and a large shopping district, is traditionally considered to be the city centre of

\footnotetext{
${ }^{2}$ Institut national de la statistique et des études économiques (National Institute for Statistics and Economic Studies).

${ }^{3}$ Due to the methods used by INSEE, only the estimated population is available after 1999.
} 
Lyon. Its main transportation junction, Bellecour-Sala, is located in the middle of the Peninsula. Part-Dieu, the largest shopping centre in the Lyon Urban Area, was built in the 1970s and is located to the east of the Peninsula.

There are 812 TAZs in the Lyon Urban Area (see Figure 1). A zone corresponds to a French statistical unit IRIS (les îlots regroupés pour l'information statistique). The average zonal population slightly exceeds two thousand inhabitants. In the current paper, a zone is used as the spatial unit of data collection and analysis.

A peculiarity of French statistics is that the data about commercial employment itself are not available. Instead, INSEE supplies the number of employees in the tertiary economic sector in 2006. This sector contains "services" in a very broad sense including commerce, education, medicine, transport and other spheres. The highest number of service employees (above 14,000) is in Part-Dieu, the second highest number (above $12,500)$ is in Bellecour-Sala.

We use travel times between the centroids of the zones. The origin-destination (O-D) matrix of travel time for 2007 for this study was obtained from the MOSART ${ }^{4}$ transportation model for the Lyon Urban Area. Though public transport is well developed in the area, the travel time by car provides better regression results. We use the travel times estimated for the travel by car in the morning peak. When the same zone is both the origin and the destination, the travel time is equal to the minimum among all the other cases, thus null values are avoided.

As McDonald and Prather (1994), we run a simple regression model of service employment density on travel time to Bellecour-Sala, which is considered to be the $\mathrm{CBD}^{5}$, in order to find positive significant residuals. McMillen and McDonald (1998) argue that employment density functions are biased if only non-zero densities are included. In our case, however, the zones are sufficiently large and only five of them,

${ }^{4}$ Modélisation et Simulation de l'Accessibilité aux Réseaux et aux Territoires (Modelling and Simulation of Accessibility to Networks and Territories).

${ }^{5}$ Using Part-Dieu as the CBD leads to a much worse regression performance. 
located in different districts, have zero densities. Of the 812 zones, fifteen have positive standardised residuals higher than 3.3, i.e. very significant (see Table 1). In further analysis we will use all these pre-identified service employment centres in order to avoid the rather subjective step of selecting a cut-off point.

The centres are described in Table 1 and shown in Figure 2. Twelve of them are situated in the $1^{\text {st }}, 2^{\text {nd }}, 3^{\text {rd }}, 6^{\text {th }}$ and $7^{\text {th }}$ arrondissements of Lyon, and the other three (Stalingrad, Charles Hernu and Gratte Ciel est) are in Villeurbanne. The service employment density and service employment to population ratio are the best measures with which to identify urban centres (McDonald, 1987; McDonald, 2008; Sivitanidou, 1996). In the current study, the former measure provides better results and so is used.

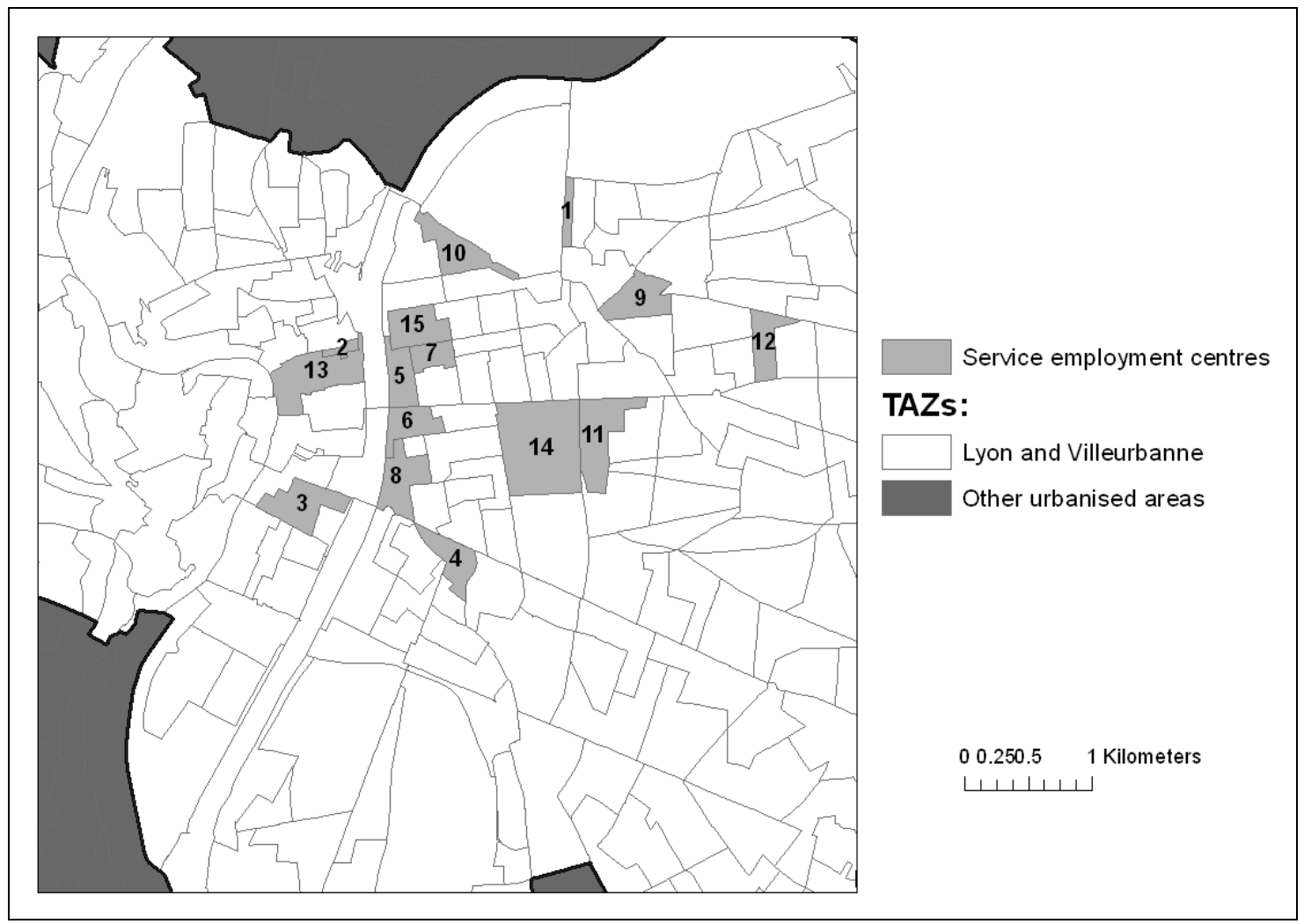

Figure 2. The pre-identified centres 
Table 1. Standardised residuals, description and indices of the pre-identified centres

\begin{tabular}{|c|c|c|c|c|c|c|c|}
\hline $\begin{array}{l}\text { Centre } \\
\text { number }\end{array}$ & $\begin{array}{l}\text { Centre } \\
\text { name }\end{array}$ & $\begin{array}{c}\text { Standardised } \\
\text { residual }\end{array}$ & $\begin{array}{c}\text { Tertiary } \\
\text { employment }\end{array}$ & Population & $\begin{array}{c}\text { Tertiary } \\
\text { employment } \\
\text { density per } \\
100 \text { sq. m }\end{array}$ & $\begin{array}{l}\text { Centrality } \\
\text { index }\end{array}$ & $\begin{array}{c}\text { Accessibility } \\
\text { index }\end{array}$ \\
\hline 1 & Stalingrad & 14.47 & 4,113 & 1 & 1,103 & 98.74 & 89.49 \\
\hline 2 & $\begin{array}{l}\text { Louis } \\
\text { Pradel }\end{array}$ & 10.73 & 1,867 & 56 & 841 & 100.00 & 95.96 \\
\hline 3 & $\begin{array}{l}\text { Bellecour- } \\
\text { Sala }\end{array}$ & 9.47 & 12,522 & 2,629 & 762 & 90.32 & 92.70 \\
\hline 4 & \begin{tabular}{|l|} 
Victor \\
Bach \\
\end{tabular} & 6.45 & 6,077 & 3,536 & 531 & 85.39 & 97.59 \\
\hline 5 & Molière & 5.51 & 4,692 & 2,577 & 463 & 85.62 & 97.87 \\
\hline 6 & Jussieu & 5.35 & 4,726 & 1,832 & 450 & 86.12 & 98.69 \\
\hline 7 & \begin{tabular}{|l} 
Saxe- \\
Bossuet
\end{tabular} & 5.13 & 2,930 & 2,207 & 430 & 92.24 & 100.00 \\
\hline 8 & $\begin{array}{l}\text { Mutualité- } \\
\text { Liberté }\end{array}$ & 4.76 & 6,232 & 3,001 & 415 & 84.94 & 98.05 \\
\hline 9 & \begin{tabular}{|l|} 
Charles \\
Hernu
\end{tabular} & 4.46 & 5,488 & 4,581 & 375 & 69.23 & 87.26 \\
\hline 10 & \begin{tabular}{|l|} 
Les \\
Belges \\
\end{tabular} & 4.25 & 5,458 & 2,226 & 364 & 70.30 & 93.39 \\
\hline 11 & \begin{tabular}{|l} 
Villette \\
Gare
\end{tabular} & 4.24 & 7,434 & 2,836 & 359 & 66.24 & 92.88 \\
\hline 12 & \begin{tabular}{|l} 
Gratte \\
Ciel est
\end{tabular} & 3.82 & 3,525 & 4,020 & 320 & 55.84 & 78.36 \\
\hline 13 & $\begin{array}{l}\text { Terreaux- } \\
\text { Bat } \\
\text { d'Argent }\end{array}$ & 3.82 & 7,782 & 3,727 & 340 & 82.37 & 95.16 \\
\hline 14 & Part-Dieu & 3.48 & 14,205 & 2,869 & 311 & 71.49 & 98.46 \\
\hline 15 & $\begin{array}{l}\text { Marechal } \\
\text { Lyautey }\end{array}$ & 3.35 & 3,978 & 3,086 & 300 & 88.30 & 98.62 \\
\hline
\end{tabular}

\section{Centrality and accessibility measures}

A service centrality index for zone $i$ is calculated with a simple gravity-like model:

$$
C I_{i}=\sum_{j=1}^{N} \frac{A_{j}}{t t_{i j}}
$$

where $A_{j}$ - the attraction of zone $j$;

$t t_{i j}$ - the travel time from zone $i$ to zone $j^{6}$;

$N-$ the number of zones.

\footnotetext{
${ }^{6}$ Travel time squared or the square root of travel time as the denominator does not lead to significant changes in the result.
} 
The attraction of a zone is its service employment density. The normalised service centrality indices calculated for the fifteen pre-identified centres are shown in Table 1 , where $C I_{i}$ for each zone is divided by the maximum value and multiplied by 100, as in Thériault et al. (2005). Figure 3 shows the clusters ${ }^{7}$ of the normalised centrality indices grouped into five classes.

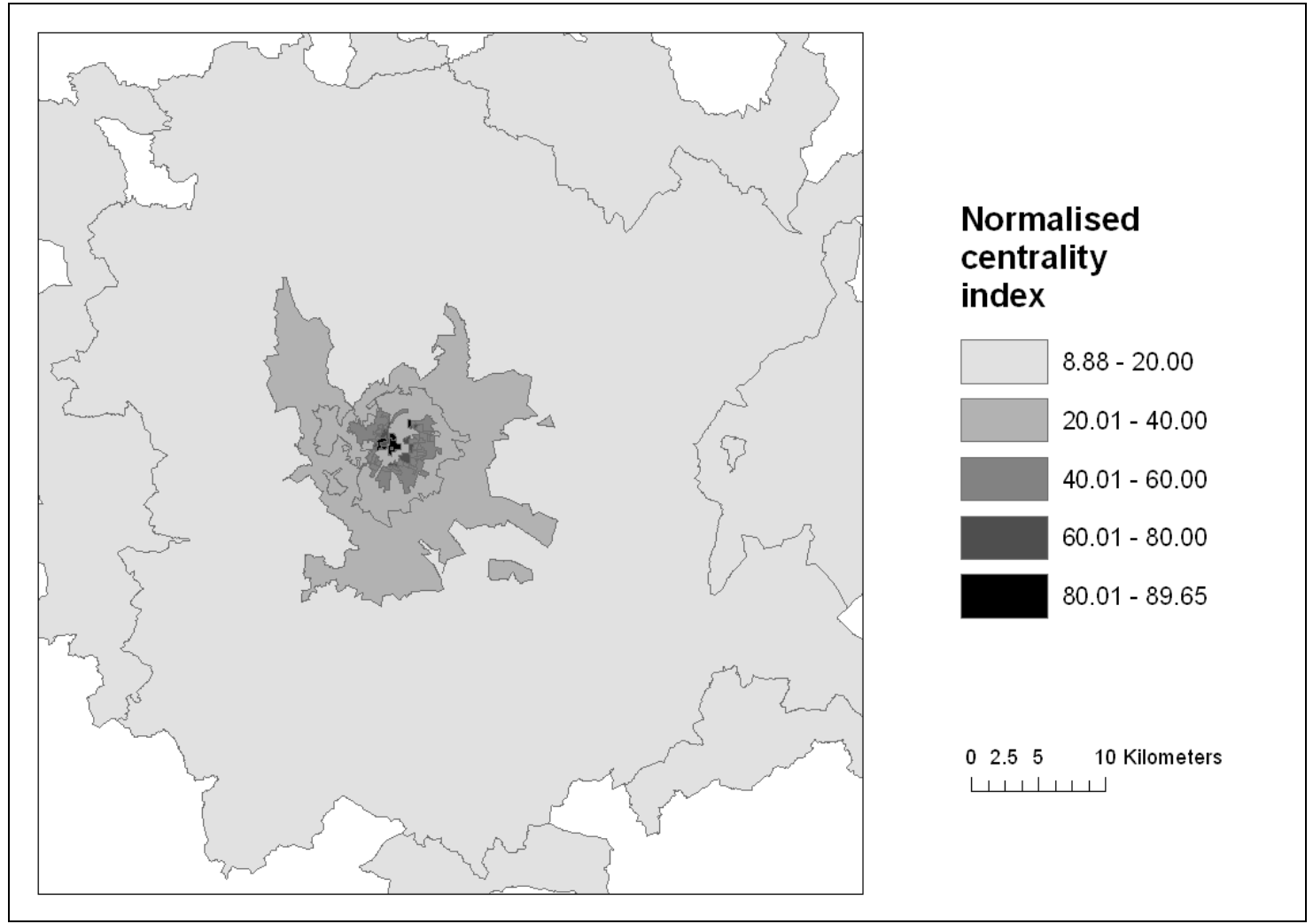

Figure 3. Clusters of centrality indices

In the remaining part of this section, we mainly follow the approach of Thériault et al. (2005) with respect to accessibility indices. The data source is a travel survey conducted in the Lyon Urban Area in the period from November 2005 to April 2006. It involved face-to-face interviews with 11,229 households asked about their typical weekday travel behaviour. We used the data on trips from home to shops by car. There were 593 responses, where the median travel time was 5.7 minutes.

\footnotetext{
${ }^{7}$ Hereafter, clusters are created with the method based on fuzzy equality proposed in Kryvobokov (2005). The advantage of the method is that the number of clusters is not determined a priori. Indices for clusters presented in the figures are calculated as a weighted average in a cluster with areas of zones used as weights.
} 
As in Thériault et al. (2005), we estimate a suitability index applying fuzzy membership and using the $50^{\text {th }}$ percentile and $90^{\text {th }}$ percentile satisfaction thresholds from the survey for travel times from the O-D matrix. Any travel time less than the observed $50^{\text {th }}$ percentile is seen to be acceptable. A travel time larger than the $90^{\text {th }}$ percentile is unsatisfactory. Intermediate cases yield satisfaction levels obtained by linear interpolation. A suitability index $S_{i j}$ for travelling from zone $i$ to zone $j$ is calculated by the following formula from the aforementioned source:

$$
\begin{aligned}
& S_{i j}=1 \quad \forall \quad t t_{i j} \leq C_{50}, \\
& S_{i j}=1-\left(\frac{t t_{i j}-C_{50}}{C_{90}-C_{50}}\right) \forall \quad C_{50}<t t_{i j}<C_{90}, \\
& S_{i j}=0 \quad \forall \quad t t_{i j} \geq C_{90},
\end{aligned}
$$

where $t_{i j}$ - the travel time from zone $i$ to zone $j$;

$C_{50}-$ the $50^{\text {th }}$ percentile of the observed travel time;

$C_{90}-$ the $90^{\text {th }}$ percentile of the observed travel time.

Table 2 includes the values of percentiles and the number of cases in the O-D matrix, where the suitability index has a value of unity, between zero and unity, or zero.

Table 2. Description of suitability index

\begin{tabular}{|c|c|c|c|c|}
\hline \multirow{2}{*}{$C_{50}$, minutes } & \multirow{2}{*}{$C_{90}$, minutes } & \multicolumn{4}{|c|}{ Number of cases where } \\
\cline { 3 - 5 } & & $S_{i j}=1$ & $0<S_{i j}<1$ & $S_{i j}=0$ \\
\hline 5.69 & 18.49 & 11,530 & 157,079 & 490,735 \\
\hline
\end{tabular}

A service accessibility index for zone $i$ is calculated as follows:

$$
A I_{i}=\sum_{j=1}^{N} S_{i j} A_{j}
$$

where $S_{i j}$ - the suitability index for travelling from zone $i$ to zone $j$; 
$A_{j}$ - the attraction of zone $j$

$N-$ the number of zones.

The attraction of a zone is its service employment density. In contrast to Thériault et al. (2005), we do not multiply the suitability index by the population of the zone. This is because in our study we are not analysing how many people can reach a particular zone, but rather we are analysing how attractive a zone is, taking into account the service employment of those zones, which can be reached from this particular zone.

The normalised service accessibility indices calculated for the fifteen preidentified centres are shown in Table 1 , where $A I_{i}$ for each zone is divided by the maximum value and multiplied by 100 . Figure 4 shows the clusters of the normalised accessibility indices grouped into five classes.

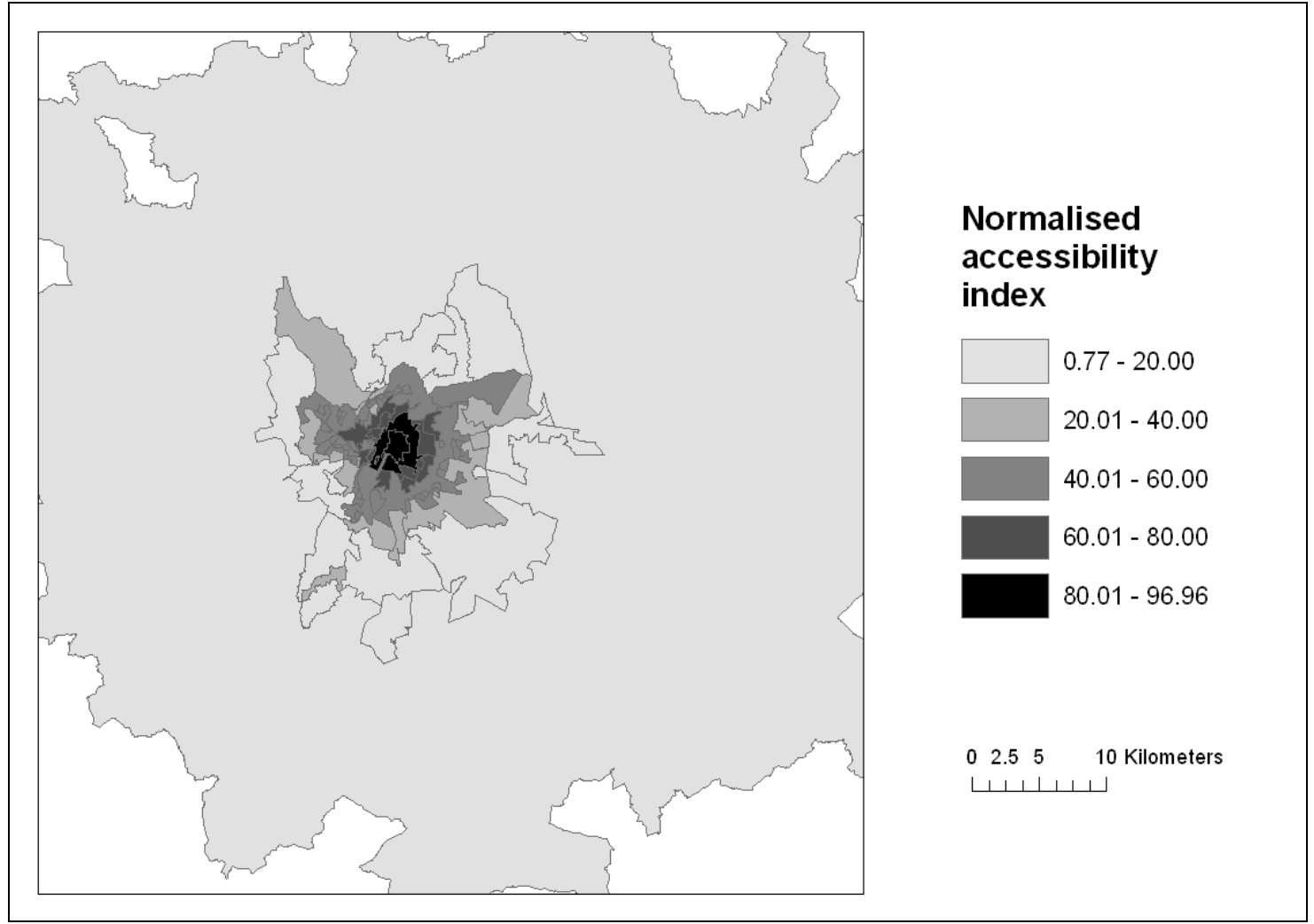

Figure 4. Clusters of accessibility indices

Our preliminary finding is that there are no important service employment centres outside Lyon and Villeurbanne. Spatially, in many cases, the centrality indices 
form belts around the central part of the Lyon Urban Area with peak values in the city core (see Figure 3). The spatial configuration of the accessibility indices is more complex; however, their structure also resembles belts (see Figure 4). For remote locations, where distances from the identified centres are much longer than distances between the centres themselves, the centres are "merged" into a city core, like a whole city becomes a point on a smaller-scale map. Thus, to understand the individual influences of the identified centres, it is better to focus on real estate prices in the central part of the Lyon Urban Area.

\section{Hedonic model of apartment prices}

\subsection{Data and model specification}

In a hedonic price model, the dependent variable is price and the independent variables are real estate attributes and location attributes. The estimated parameters in the OLS can be interpreted as the willingness to pay for different attributes (Rosen, 1974). Hedonic regression analysis is widely used in investigations of real estate around the world. Examples of its application to apartment prices include: Asabere and Huffman (1996), So et al. (1997), Watkins (1998), Brañas-Garza et al. (2002), and Björklund and Klingborg (2005).

The data on sale prices and apartment attributes were provided by Perval, which collects information about real estate transactions in France. Data on approximately 10,000 apartment sales selected randomly from all sales in the central part of the Lyon Urban Area in the period 1997-2008 were obtained. After deleting observations with incomplete data, 4,362 apartments remained. The apartments are mainly located in Lyon and Villeurbanne and also in the surrounding urbanised area (Figure 5). 


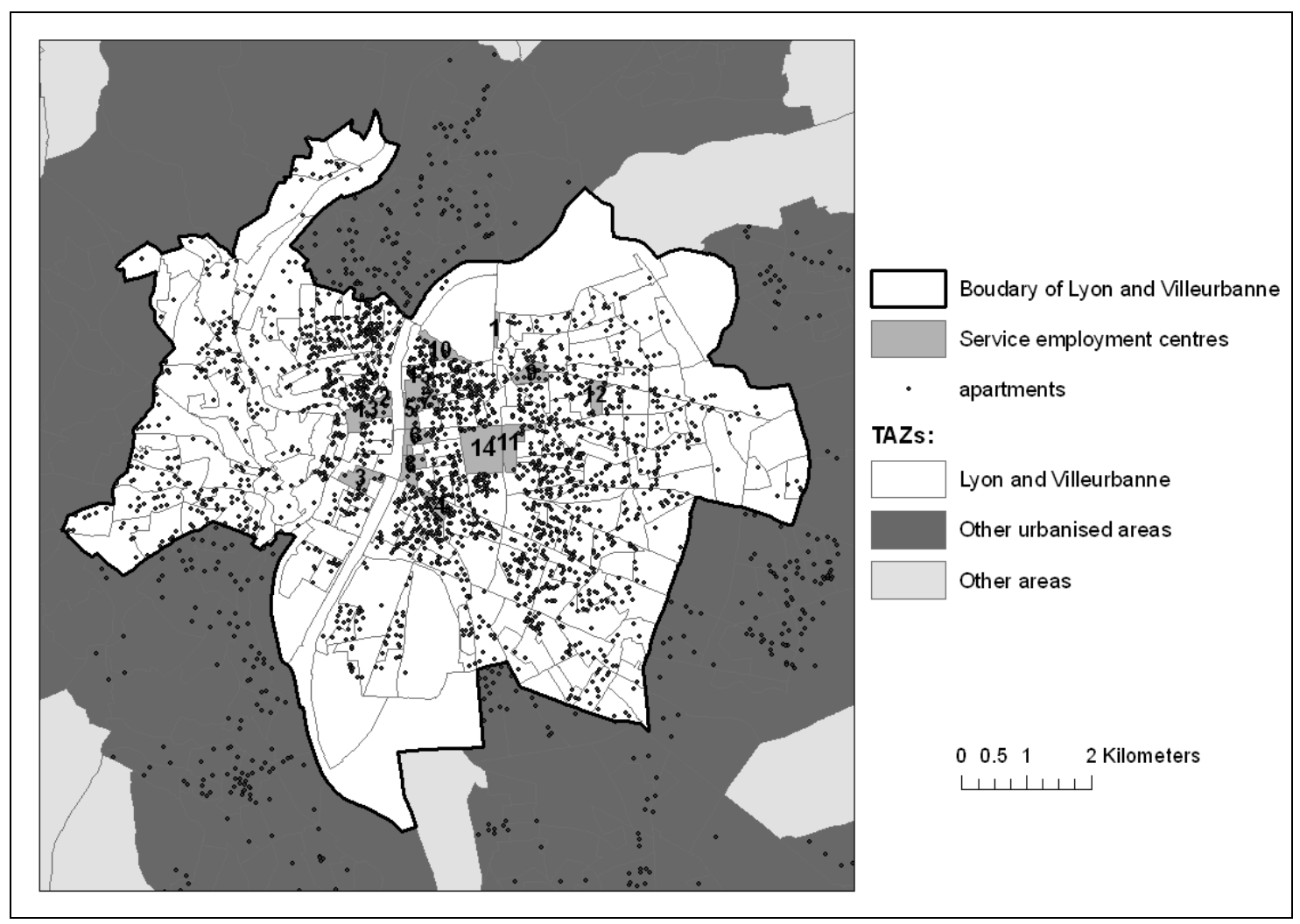

Figure 5. Location of apartments

The definition of variables and descriptive statistics are given in Table 3. It contains information about transactions, as well as about apartment attributes and location attributes. It does not include the number of rooms, because the dummies for them are highly correlated with apartment area and are not significant if included in the hedonic model. Many observations contain no data about the number of parking places, number of cellars, and quality of view; therefore the specific dummy variables were created.

The location variables in Table 3 include the percentage of middle-income households, the percentage of high-income households in zones, and dummies for proximity to water and location in one of four ad hoc districts. The percentages of middle- and high-income households in zones were obtained from the INSEE data. The middle-income group includes households in the middle $60 \%$ of the income range and the high-income group is composed of the $20 \%$ households with the highest income. A 
dummy for location within a 100 metre buffer created for rivers and lakes is a proxy for a water view, though we admit that in densely built areas water is not necessarily visible from each apartment. The four ad hoc districts, created as proxies for submarkets, are quite large, but relatively homogenous territories, divided by water frontiers and the boundaries of the urbanised area. District 1 is the Peninsula and the urbanised area to the north of it, between the Rhône and the Saône. District 2 is an urbanised area on the left bank of the Rhône. District 3 is an urbanised area on the right bank of the Saône. District 4 is the less urbanised territory, which occupies most of the area in Figure 1. The following attributes are used as default values in the hedonic model: Year97, Bath1, Park0, FloorGr, Constr1981_1991, CondGood, ViewGood, Cellar0 and District1.

Table 3 also gives the travel times to each of the pre-identified centres and includes the definition and descriptive statistics of the normalised centrality index and accessibility index for the zones, where the analysed apartments are located. The logarithmic transformations of Area, \%MidIncome, \%HighIncome and travel times are used. The dependent variable is the logarithm of Price. 
Table 3. Definition of variables and descriptive statistics

\begin{tabular}{|c|c|c|c|c|c|}
\hline Variable & Description & Mean & Minimum & Maximum & Std. deviation \\
\hline Price & Transaction price, Euros & $123,635.86$ & 12,196 & $1,120,000$ & 76,838 \\
\hline $\begin{array}{l}\text { Year97- } \\
\text { Year08 }\end{array}$ & $\begin{array}{c}\text { Dummies for year of } \\
\text { transaction }\end{array}$ & $0.02-0.13$ & 0 & 1 & $0.15-0.34$ \\
\hline Area & $\begin{array}{c}\text { Apartment area, square } \\
\text { metres }\end{array}$ & 69.05 & 8 & 301 & 28.14 \\
\hline Bath1-Bath3 & $\begin{array}{c}\text { Dummies for number of } \\
\text { bathrooms }\end{array}$ & $<0.01-0.93$ & 0 & 1 & $0.05-0.26$ \\
\hline ParkUn & $\begin{array}{l}\text { Dummy for cases with no } \\
\text { data about parking places }\end{array}$ & 0.26 & 0 & 1 & 0.44 \\
\hline Park0-Park3 & $\begin{array}{l}\text { Dummies for number of } \\
\text { parking places }\end{array}$ & $<0.01-0.50$ & 0 & 1 & $0.06-0.50$ \\
\hline FloorGr & Dummy for ground floor & 0.13 & 0 & 1 & 0.33 \\
\hline Floor1 & Dummy for storey 1 & 0.19 & 0 & 1 & 0.39 \\
\hline Floor2_4 & Dummy for storey 2 to 4 & 0.49 & 0 & 1 & 0.50 \\
\hline Floor5_8 & Dummy for storey 5 to 8 & 0.18 & 0 & 1 & 0.38 \\
\hline Floor9+ & $\begin{array}{c}\text { Dummy for storey } 9 \text { or } \\
\text { more }\end{array}$ & 0.02 & 0 & 1 & 0.14 \\
\hline $\begin{array}{l}\text { Constr }<1850- \\
\text { Constr1992< }\end{array}$ & $\begin{array}{c}\text { Dummies for period of } \\
\text { construction }\end{array}$ & $0.03-0.34$ & 0 & 1 & $0.17-0.48$ \\
\hline CondGood & Dummy for good state & 0.81 & 0 & 1 & 0.39 \\
\hline CondMed & $\begin{array}{c}\text { Dummy for state when } \\
\text { some maintenance is } \\
\text { needed }\end{array}$ & 0.16 & 0 & 1 & 0.37 \\
\hline CondBad & $\begin{array}{l}\text { Dummy for state when } \\
\text { renovation is needed }\end{array}$ & 0.03 & 0 & 1 & 0.17 \\
\hline ViewNo & $\begin{array}{c}\text { Dummy for cases with no } \\
\text { data about view }\end{array}$ & 0.60 & 0 & 1 & 0.49 \\
\hline ViewGood & $\begin{array}{l}\text { Dummy for view } \\
\text { increasing value }\end{array}$ & 0.38 & 0 & 1 & 0.48 \\
\hline ViewBad & $\begin{array}{l}\text { Dummy for view } \\
\text { decreasing value }\end{array}$ & 0.02 & 0 & 1 & 0.13 \\
\hline $\begin{array}{l}\text { Cellar0- } \\
\text { Cellar2 }\end{array}$ & $\begin{array}{l}\text { Dummies for number of } \\
\text { cellars }\end{array}$ & $0.02-0.33$ & 0 & 1 & $0.13-0.47$ \\
\hline Garden & $\begin{array}{l}\text { Dummy for existence of } \\
\text { garden }\end{array}$ & 0.05 & 0 & 1 & 0.22 \\
\hline Terrace & $\begin{array}{c}\text { Dummy for existence of } \\
\text { terrace }\end{array}$ & 0.09 & 0 & 1 & 0.29 \\
\hline \%MidIncome & $\begin{array}{l}\text { Percentage of middle- } \\
\text { income households }\end{array}$ & 57.96 & 42.70 & 66.20 & 3.30 \\
\hline \%HighIncome & $\begin{array}{l}\text { Percentage of high- } \\
\text { income households }\end{array}$ & 12.55 & 4.34 & 28.77 & 2.91 \\
\hline Water & $\begin{array}{l}\text { Dummy for location } \\
\text { within a } 100 \mathrm{~m} \text { buffer of } \\
\text { water }\end{array}$ & 0.03 & 0 & 1 & 0.18 \\
\hline $\begin{array}{l}\text { District1- } \\
\text { District4 }\end{array}$ & $\begin{array}{c}\text { Dummies for location in } \\
\text { districts }\end{array}$ & $0.01-0.16$ & 0 & 1 & $0.12-0.37$ \\
\hline $\begin{array}{l}\text { Travel time to } \\
\text { Centre } 1 \text { - } \\
\text { Travel time to } \\
\text { Centre } 15\end{array}$ & $\begin{array}{l}\text { Travel time to centre } 1- \\
\text { travel time to centre } 15\end{array}$ & $9.57-11.67$ & 0.45 & $24.43-31.28$ & $4.85-5.67$ \\
\hline $\begin{array}{c}\text { Centrality } \\
\text { Index }\end{array}$ & Centrality index & 42.19 & 13.45 & 100.00 & 17.21 \\
\hline $\begin{array}{c}\text { Accessibility } \\
\text { Index }\end{array}$ & Accessibility index & 63.23 & 0.34 & 100.00 & 27.39 \\
\hline
\end{tabular}




\subsection{Global and GWR OLS models}

The relative importance of variables in regressions is quite often discussed in the literature. As the choice of one or another concept of relative importance often affects conclusions (Kruskal and Majors, 1989), it is important to select a meaningful measure. We can use a contribution to adjusted $R^{2}$ and an unstandardised regression coefficient. The latter is appropriate to compare variables, which have the same unit of measurement, e.g. travel times to different centres measured in minutes. The comparison of travel times with indices is more complicated. One could consider a standardised regression coefficient for this purpose. However, this beta coefficient has been much criticised in the statistics literature (e.g. Darlington, 1990; Bring, 1994). As King (1986) noted, this measure is a mixture of the estimated effect and the standard deviation, which should be analysed separately.

Perhaps a better approach to the evaluation of different models is to define the in-sample estimates and then use the result for an ex-sample prediction. For this purpose, as e.g. in Bourassa et al. (2003), we randomly select $80 \%$ of observations as the in-sample and the other $20 \%$ are the ex-sample. Using the latter, we calculate the percentages of predictions that deviate by less than $10 \%$ and $20 \%$ from the actual sale prices.

To investigate the existence of multicollinearity, we estimate the maximum of variance inflationary factors $(V I F)$. The principle that a VIF in excess of 10 indicates multicollinearity is usually used in the literature (e.g. Seiler et al., 2001; Thériault et al., 2005). We measure global spatial autocorrelation in the error term with Moran's I (Anselin, 1995, Dubin, 1998; see also the empirical examples in De Graaff et al., 2001; Munroe, 2007), which is a weighted correlation coefficient ranging between - 1 and 1 . In this paper, it is calculated with the row-standardised weight matrix of inverse squared distances. 
The influence of the pre-identified centres was examined in the following way.

First, the OLS model with only apartment variables was estimated. This model with the adjusted $R$-square of 0.781 does not contain the dummies for construction periods, which are correlated with location. Its significant attributes are presented in the Appendix. We then added the location attributes and travel time to each of the fifteen pre-identified centres, one at a time. Thus we obtained fifteen global models with adjusted $R$-squared varying in the range $0.819-0.849$. We do not report standard errors of regression and F-values, because, as shown in Söderberg and Janssen (1999), as the number of variables is the same for each run, the case which has the minimum standard error of regression, has maximum $R$-squared, maximum $F$-value and maximum adjusted $R$-squared. Sorting the adjusted $R$-squared from high to low, we added all fifteen variables to the equation and then excluded them one by one from the bottom in order to obtain a model with an acceptable VIF. Due to high multicollinearity, an acceptable VIF can only be achieved with a small number of centres in a model.

The two best global OLS models: with travel times to the CBD (Centre 3) and Les Belges (Centre 10), and with travel times to Les Belges (Centre 10) and Jussieu (Centre 6) are named Duocentric 1 and Duocentric 2, respectively, in Table $4^{8}$. It should be noted that in the former model, the travel time to Les Belges outweighs that to the CBD. However, in the latter model, the travel time to Jussieu outweighs that to Les Belges. The estimates of the former model that are significant at the 5\% level are presented in the Appendix. Other location variables behave as follows. Water does not significantly influence apartment prices. \%MidIncome is more significant than \%HighIncome, perhaps because of the relatively small percentage of high-income households. District1, used as the default ad hoc district, is the most attractive one, whereas District2 is the least attractive urbanised ad hoc district, and less urbanised

\footnotetext{
${ }^{8}$ In Table 4, $t$-values for global OLS and asymptotic $t$-values for spatial models are in parentheses. VIF always has its maximum for Year03. There are median values for GWR coefficients.
} 
District4 has the highest negative coefficient. The extracted results for the alternative models: the model with longitude $\mathrm{X}$ and latitude $\mathrm{Y}^{9}$, the monocentric model, and those, which use a centrality index or an accessibility index instead of travel times, are also presented in Table 4. For all the models, a Jarque-Bera test and a Breusch-Pagan test indicate no rejections of the assumptions of normality and heteroskedasticity. The goodness-of-fit and prediction of the global models with two centres is better than those of the alternative models. The model with coordinates predicts prices better than other alternative specifications, but is worse than the duocentic models. Among the global models, Moran's I for residuals is the lowest for the duocentric models and the highest for the monocentric model.

To detect local peculiarities, we apply a geographically weighted regression (GWR) (Brunsdon et al., 1996) as an alternative to global regression modelling. The GWR model used in the study is OLS and the error term is Gaussian. The fixed kernel type is used; the kernel bandwith is determined by the Akaike Information Criterion. In the current application of the GWR, a separate equation is solved for each observation, and the overall results are reported in this paper.

\footnotetext{
${ }^{9}$ This model suggested by Ross et al. (2009) as an alternative to models with distance variables is tested in our OLS group. It was impossible to include in this model X-squared and Y-squared due to enormous multicollinearity.
} 
Table 4. The extracted results of hedonic models

\begin{tabular}{|c|c|c|c|c|c|c|c|c|c|c|c|}
\hline \multirow[b]{2}{*}{ Model } & \multicolumn{5}{|c|}{ Estimates } & \multirow[b]{2}{*}{ 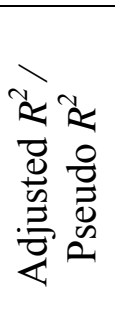 } & \multirow[b]{2}{*}{ 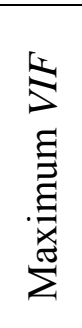 } & \multirow[b]{2}{*}{ 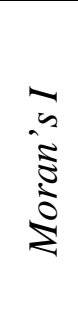 } & \multirow[b]{2}{*}{$\begin{array}{l}\frac{0}{0} \\
\text { हิ } \\
\frac{5}{0} \\
\frac{1}{\approx 2}\end{array}$} & \multirow[b]{2}{*}{ 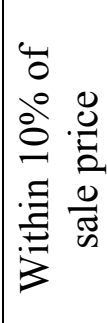 } & \multirow[b]{2}{*}{ 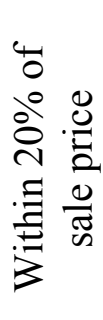 } \\
\hline & 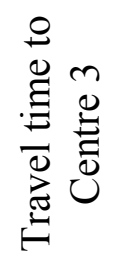 & 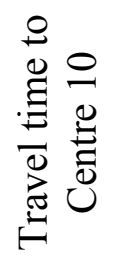 & 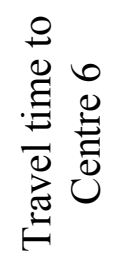 & & 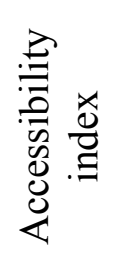 & & & & & & \\
\hline Global OLS & & & & & & & & & & & \\
\hline & $\begin{array}{c}-0.148 \\
(-12.63)\end{array}$ & $\begin{array}{c}-0.174 \\
(-19.26)\end{array}$ & - & - & - & 0.850 & 5.98 & 0.28 & - & 42.7 & 69.6 \\
\hline Duocentric 2 & - & $\begin{array}{l}-0.085 \\
(-6.75)\end{array}$ & $\begin{array}{c}-0.195 \\
(-13.61)\end{array}$ & - & - & 0.851 & 5.98 & 0.28 & - & 42.5 & 70.1 \\
\hline $\mathrm{X}$ and $\mathrm{Y}$ & - & - & - & - & - & 0.834 & 5.99 & 0.33 & - & 42.5 & 68.9 \\
\hline Monocentric & $\begin{array}{c}-0.225 \\
(-19.38)\end{array}$ & - & - & - & - & 0.834 & 5.97 & 0.34 & - & 39.1 & 68.1 \\
\hline Centrality & - & - & - & $\begin{array}{c}0.009 \\
(26.81)\end{array}$ & - & 0.847 & 5.97 & 0.29 & - & 42.3 & 68.1 \\
\hline Accessibility & - & - & - & - & $\begin{array}{c}0.005 \\
(25.11)\end{array}$ & 0.844 & 5.97 & 0.30 & - & 40.6 & 68.6 \\
\hline GWR & & & & & & & & & & & \\
\hline & -0.108 & -0.158 & - & - & - & 0.876 & - & 017 & - & 43.9 & 71.2 \\
\hline Duoc & & -0101 & -0.137 & - & - & 0.876 & - & 0. & - & 43.5 & 71.9 \\
\hline Mono & -0.134 & - & - & - & - & 0.872 & - & 0.1 & - & 42.0 & 71.4 \\
\hline Cent & - & - & - & 0.006 & - & 0.874 & - & & - & 41.6 & 70.9 \\
\hline Access & - & - & - & - & 0.005 & 0.873 & - & 0.18 & - & 42.7 & 71.1 \\
\hline & & & & & & & & & & & \\
\hline Duocentric 1 & $\begin{array}{l}-0.137 \\
(-11.71)\end{array}$ & $\begin{array}{l}-0.137 \\
(-12.06)\end{array}$ & - & - & - & 0.853 & - & 0.28 & 0.324 & 42.5 & 70.2 \\
\hline Duocentric 2 & - & $\begin{array}{l}-0.063 \\
(-4.63)\end{array}$ & $\begin{array}{l}-0.180 \\
(-12.36)\end{array}$ & - & - & 0.854 & - & 0.28 & 0.256 & 43.2 & 70.3 \\
\hline Monocentric & $\begin{array}{c}-0.162 \\
(-13.76)\end{array}$ & & - & - & - & 0.847 & - & 0.30 & 0.756 & 40.0 & 67.4 \\
\hline Centrality & - & - & - & $\begin{array}{c}0.007 \\
(17.77)\end{array}$ & - & 0.851 & - & 0.28 & 0.395 & 41.7 & 68.5 \\
\hline Accessibility & - & - & - & - & $\begin{array}{c}0.004 \\
(13.95) \\
\end{array}$ & 0.846 & - & 0.30 & 0.238 & 41.4 & 68.6 \\
\hline $\begin{array}{l}\text { Spatial error } \\
\text { Duocentric } 1\end{array}$ & $\begin{array}{l}-0.123 \\
(-8.56)\end{array}$ & $\begin{array}{c}-0.159 \\
(-13.15)\end{array}$ & - & - & - & 0.855 & - & 0.27 & 0.881 & 44.0 & 73.1 \\
\hline Duocentric 2 & - & $\begin{array}{l}-0.095 \\
(-6.54)\end{array}$ & $\begin{array}{l}-0.164 \\
(-9.99)\end{array}$ & - & - & 0.856 & - & 0.27 & 0.869 & 43.8 & 72.9 \\
\hline Monocentric & $\begin{array}{l}-0.146 \\
(-9.91)\end{array}$ & 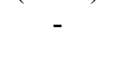 & - & - & - & 0.848 & - & 0.30 & 0.981 & 44.2 & 72.6 \\
\hline Centrality & - & - & - & $\begin{array}{c}0.006 \\
(15.09)\end{array}$ & - & 0.853 & - & 0.28 & 0.931 & 40.8 & 66.9 \\
\hline Accessibility & - & - & - & - & $\begin{array}{c}0.005 \\
(12.30)\end{array}$ & 0.850 & - & 0.29 & 0.954 & 44.6 & 72.4 \\
\hline
\end{tabular}

The extracted GWR results are shown in Table 4. For them, the goodness-of-fit of the models with two centres are also higher than those of alternative models, though the differences are less than in the global OLS. Moran's I for the indices is $1 \%$ better than that for the monocentric model, but $1 \%$ worse than that for the duocentric models. In all cases, the GWR models outperform the global OLS models with respect to 
goodness-of-fit. Naturally, the spatial autocorrelation is also better controlled by the GWR. The predictive capacity measured using average estimates in each zone also demonstrates the superiority of the duocentric models, although the GWR monocentric model predicts not only better than the models with indices, but also better than Duocentric 1 within $20 \%$ of the sale price.

\subsection{Spatial lag and spatial error models}

Moran's I indicates that quite high spatial autocorrelation still exists ${ }^{10}$. Spatial econometrics can be applied to take account of spatial dependence and spatial heterogeneity. Discussions of spatial models can be found in Anselin (1988), Dubin (1998) and LeSage and Pace (2009). We control for spatial effects with two models: a spatial lag model, where a dependent variable is not only a function of independent variables, but also of the dependent variables in nearby areas; and a spatial error model, where the error term is a function of the errors in neighbouring areas. In both cases, the weight matrix includes row-standardised binary weights, which are equal to unity for neighbouring observations and zero otherwise. The band is defined in such a way that there is at least one neighbour for all observations. Such a weighting scheme avoids the correlation of spatial structure with travel time variables (this problem, with respect to a distance variable, is discussed in Wilhelmsson, 2002).

Parameter estimates in global OLS, GWR and a spatial error model have a straightforward interpretation as partial derivatives of the dependent variable with respect to the explanatory variable in question. In a model containing the spatial lag of the dependent variable, the interpretation of parameters becomes richer and more complicated (LeSage and Pace, 2009). Kim et al. (2003) have shown that if a unit change was induced at every location and a weight matrix is row-standardised, the

\footnotetext{
${ }^{10}$ We should admit, however, that Moran's I is highly dependent on a weighting scheme. With the rowstandardised binary weights the lowest Moran's $I$ is 0.04 and the highest is 0.10 . Nevertheless, we focus on Moran's I calculated with the row-standardised weight matrix of inverse squared distances.
} 
marginal effect can be calculated as a spatial lag estimate multiplied by $(1-\rho)^{-1}$. LeSage and Pace (2009) have called this simple form a summary measure of total impacts.

The estimates of the duocentric spatial models with travel times to the CBD and Les Belges are presented in the Appendix. For most non-location variables the estimates of the spatial models are slightly lower than those of the OLS. The coefficients and significance of the travel time to Les Belges (Centre 10) are higher than those to the CBD (Centre 3) in the spatial error model and they (as well as their marginal effects) are practically equal in the spatial lag model.

The extractions of all the spatial models are presented in Table 4. A BreuschPagan test indicates that the assumption of heteroskedasticity is not rejected. Lower rho, i.e. lower spatial dependency, is observed for the duocentric models and for the models with indices. Lambda shows a similar tendency, though to a lesser degree; it is lowest for the duocentric models. For the spatial models, Table 4 contains pseudo $R^{2}$. Both spatial models explain the variation in price better than the global OLS, but worse than the GWR OLS. Interestingly, in most cases the spatial autocorrelation of the residuals was either not decreased or decreased by only $1 \%$ in comparison with the global OLS. Only the monocentric model demonstrates a larger decrease in Moran's I. This may be due to the weighting scheme which was applied.

Comparing the spatial lag results with other models, we can see that while the marginal effect of an accessibility index $(0.005)$ is the same as the estimate in other models, the marginal effects of travel time variables are quite large, for example in Duocentric Model 1 it is equal to -0.203 for both of the centres that were examined.

The ex-sample predictions are calculated with the average in-sample dependent variable for the spatial lag model and with an average in-sample prediction error in each zone for the spatial error model. In most cases the best predictions are obtained with the duocentric models. Only in the spatial error model within the $10 \%$ interval of sale price 
the prediction is the best with an accessibility index, while it is second best with the monocentric model.

In general, when we control for spatial effects, the predictive capacity usually increases, especially with the spatial error model, though there are exceptions, the most visible being the model with a centrality index. The spatial models are no more helpful than the OLS when determining the leaderships or ranking among the three selected centres.

\section{Conclusions}

The first conclusion in this study concerns the importance of particular centres when modelling apartment prices in the Lyon Urban Area. The best results were obtained with travel times to three centres: Bellecour-Sala traditionally viewed as the $\mathrm{CBD}$, Les Belges, and Jussieu. However, due to high correlation between them, it was impossible to include all three in a single model (this can be done in a future study with a factor analysis), and two alternative duocentric models were created instead. We acknowledge, as in Söderberg and Janssen (1999), that we did not determine the alternative CBDs in the traditional CBD sense. The two subcentres found to be important are not the leaders according to their service employment attributes (see Table 1), but rather are highly desirable residential locations ${ }^{11}$.

The second conclusion is related to the three concepts: identified urban centres, an "objective" centrality index, and a "subjective" accessibility index. In most cases both duocentric models have the highest predictive capacity. There are no large differences in the predictions for the GWR and the spatial lag models with one or another index, although an accessibility index provides much better prediction with the spatial error model. Thus, the answer to the question asked in the title is positive. However, if a model is spatially weighted or the spatial effects are controlled, it is

\footnotetext{
${ }^{11}$ For example, high quality schools are located in Les Belges and it is adjacent to Park de la Tête d'Or, which is regarded as the best urban park in France.
} 
usually less important which of the concepts is applied. This is especially noticeable with the GWR methodology, where the differences between the results are rather marginal.

\section{Acknowledgements}

The study is part of project PLAINSUDD sponsored though French ANR (number ANR-08-VD-00). The author is grateful to Perval and Pierre-Yves Peguy for providing data on apartment prices and attributes and to Nicolas Ovtracht and Valérie Thiebaut for calculating the O-D matrices of travel times and the coordinates of apartments. The author also thanks Alain Bonnafous, Fabrice Marchal, Dominique Bouf, Gunther Maier and the anonymous referees for valuable suggestions and John Mc Breen for proofreading the paper. The GWR software was distributed by its developers, Chris Brunsdon, Stewart Fotheringham and Martin Charlton. The publically released $\mathrm{GeoDa}^{\mathrm{TM}}$ software by Luc Anselin was used for spatial models. The availability of both software products is gratefully acknowledged. 
Appendix. Duocentric 1: global OLS without location attributes, global OLS, and spatial models

\begin{tabular}{|c|c|c|c|c|c|c|c|c|c|}
\hline \multirow[b]{2}{*}{ Variable } & \multicolumn{2}{|c|}{$\begin{array}{c}\text { Global OLS, no } \\
\text { location attributes }\end{array}$} & \multicolumn{3}{|c|}{ Global OLS } & \multicolumn{2}{|c|}{ Spatial lag } & \multicolumn{2}{|c|}{ Spatial error } \\
\hline & $\begin{array}{l}\text { Coeffi- } \\
\text { cient }\end{array}$ & $t$-value & $\begin{array}{l}\text { Coeffi- } \\
\text { cient }\end{array}$ & $t$-value & VIF & $\begin{array}{l}\text { Coeffi- } \\
\text { cient }\end{array}$ & $\begin{array}{l}\text { Assym- } \\
\text { ptotic } \\
t \text {-value }\end{array}$ & $\begin{array}{l}\text { Coeffi- } \\
\text { cient }\end{array}$ & $\begin{array}{c}\text { Assym- } \\
\text { ptotic } \\
t \text {-value }\end{array}$ \\
\hline Constant & 6.982 & 106.34 & 4.364 & 11.34 & - & 0.522 & 0.66 & 4.584 & 11.92 \\
\hline $\begin{array}{l}\text { Travel time to } \\
\text { Centre } 3\end{array}$ & - & - & -0.148 & -12.63 & 2.129 & -0.137 & -11.71 & -0.123 & -8.56 \\
\hline $\begin{array}{l}\text { Travel time to } \\
\text { Centre } 10\end{array}$ & - & - & -0.174 & -19.26 & 1.678 & -0.137 & -12.06 & -0.159 & -13.15 \\
\hline Year99 & 0.140 & 3.90 & 0.099 & 3.32 & 4.303 & 0.095 & 3.20 & 0.092 & 3.13 \\
\hline Year00 & 0.197 & 5.43 & 0.158 & 5.24 & 4.154 & 0.156 & 5.23 & 0.155 & 5.25 \\
\hline Year01 & 0.268 & 7.59 & 0.247 & 8.42 & 4.901 & 0.241 & 8.29 & 0.243 & 8.41 \\
\hline Year02 & 0.319 & 9.04 & 0.307 & 10.48 & 5.036 & 0.299 & 10.33 & 0.302 & 10.48 \\
\hline Year03 & 0.480 & 13.91 & 0.458 & 16.01 & 5.979 & 0.452 & 15.93 & 0.456 & 16.21 \\
\hline Year04 & 0.656 & 18.66 & 0.638 & 21.88 & 5.117 & 0.630 & 21.80 & 0.637 & 22.19 \\
\hline Year05 & 0.803 & 22.87 & 0.791 & 27.17 & 5.127 & 0.783 & 27.14 & 0.788 & 27.48 \\
\hline Year06 & 0.932 & 26.11 & 0.908 & 30.59 & 4.496 & 0.901 & 30.66 & 0.906 & 31.03 \\
\hline Year07 & 1.027 & 28.57 & 1.003 & 33.56 & 4.332 & 0.997 & 33.70 & 1.002 & 34.11 \\
\hline Year08 & 0.968 & 24.21 & 0.969 & 29.18 & 2.632 & 0.963 & 29.32 & 0.966 & 29.60 \\
\hline Area & 0.902 & 66.23 & 0.922 & 80.84 & 1.442 & 0.927 & 81.91 & 0.927 & 82.24 \\
\hline Bath2 & 0.139 & 6.65 & 0.077 & 4.40 & 1.247 & 0.075 & 4.36 & 0.075 & 4.37 \\
\hline ParkUn & 0.228 & 14.78 & 0.073 & 5.08 & 2.427 & 0.070 & 4.95 & 0.057 & 3.99 \\
\hline Park1 & 0.283 & 19.93 & 0.150 & 11.54 & 2.674 & 0.145 & 11.28 & 0.138 & 10.69 \\
\hline Park2 & 0.366 & 16.70 & 0.197 & 10.13 & 1.793 & 0.192 & 9.98 & 0.182 & 9.50 \\
\hline Park3 & 0.154 & 2.03 & -0.012 & -0.19 & 1.090 & 0.191 & 3.639 & -0.026 & -0.42 \\
\hline Floor1 & 0.101 & 5.10 & 0.068 & 4.12 & 2.620 & 0.068 & 4.19 & 0.065 & 4.00 \\
\hline Floor2_4 & 0.149 & 8.31 & 0.094 & 6.26 & 3.576 & 0.094 & 6.35 & 0.092 & 6.21 \\
\hline Floor5_8 & 0.160 & 7.97 & 0.115 & 6.88 & 2.652 & 0.113 & 6.80 & 0.112 & 6.82 \\
\hline Floor9+ & 0.118 & 3.04 & 0.112 & 3.47 & 1.238 & 0.109 & 3.42 & 0.114 & 3.59 \\
\hline CondMed & -0.165 & -12.01 & -0.108 & -9.22 & 1.170 & -0.109 & -9.41 & -0.106 & -9.20 \\
\hline CondBad & -0.244 & -8.20 & -0.213 & -8.55 & 1.106 & -0.216 & -8.74 & -0.216 & -8.81 \\
\hline ViewNo & -0.030 & -2.56 & -0.037 & -4.23 & 1.130 & -0.036 & -4.18 & -0.037 & -4.30 \\
\hline ViewBad & -0.127 & -3.34 & -0.111 & -3.49 & 1.089 & -0.109 & -3.47 & -0.108 & -3.47 \\
\hline Cellar1 & -0.042 & -3.76 & 0.027 & 2.69 & 1.391 & 0.023 & 2.37 & 0.018 & 1.81 \\
\hline Cellar2 & 0.056 & 1.41 & 0.070 & 2.10 & 1.147 & 0.066 & 2.02 & 0.062 & 1.90 \\
\hline Garden & 0.099 & 3.71 & 0.057 & 2.58 & 1.534 & 0.061 & 2.75 & 0.058 & 2.65 \\
\hline Terrace & 0.111 & 5.77 & 0.054 & 3.33 & 1.370 & 0.054 & 2.37 & 0.058 & 3.64 \\
\hline Constr1850_1913 & - & - & -0.108 & -4.91 & 1.948 & -0.099 & -4.49 & -0.102 & -4.66 \\
\hline Constr1914_1947 & - & - & -0.078 & -3.68 & 1.892 & -0.071 & -3.36 & -0.071 & -3.38 \\
\hline Constr1948_1969 & - & - & -0.135 & -8.30 & 2.912 & -0.129 & -7.94 & -0.130 & -8.07 \\
\hline Constr1970_1980 & - & - & -0.107 & -6.50 & 2.295 & -0.100 & -6.12 & -0.100 & -6.16 \\
\hline Constr1992< & - & - & 0.142 & 9.55 & 3.163 & 0.143 & 9.73 & 0.142 & 9.75 \\
\hline \%MidIncome & - & - & 0.790 & 7.57 & 2.339 & 0.785 & 7.61 & 0.718 & 6.95 \\
\hline \%HighIncome & - & - & 0.114 & 4.12 & 2.736 & 0.103 & 3.78 & 0.086 & 3.14 \\
\hline District2 & - & - & -0.090 & $\begin{array}{l}-7.43 \\
\end{array}$ & 2.152 & -0.064 & -5.00 & -0.076 & -4.44 \\
\hline District3 & - & - & -0.030 & -1.96 & 2.210 & -0.025 & -1.70 & -0.040 & -2.19 \\
\hline District4 & - & - & -0.107 & -2.89 & 1.197 & -0.054 & -1.43 & -0.031 & -0.61 \\
\hline Rho & - & - & - & - & - & 0.324 & 5.58 & - & - \\
\hline Lambda & - & - & - & - & - & - & - & 0.881 & 16.42 \\
\hline
\end{tabular}




\section{References}

Anas, A. and Kim, I. (1996), General Equilibrium Models of Polycentric Urban Land Use with Endogenous Congestion and Job Agglomeration, Journal of Urban Economics, 40 (2), pp. 232-256.

Anselin, L. (1988), Spatial Econometrics: Methods and Models, Kluwer Academic Publishers, Dordrecht.

Anselin, L. (1995), Local Indicators of Spatial Association - LISA, Geographical Analysis, 27 (2), pp. 93-115.

Asabere, P. K. and Huffman, F. E. (1996), Thoroughfares and Apartment Values, Journal of Real Estate Research, 12 (1), pp. 9-16.

Björklund, K. and Klingborg, K. (2005), Correlation between Negotiated Rents and Neighbourhood Quality: A Case Study of Two Cities in Sweden, Housing Studies, 20 (4), pp. 627-648.

Bourassa, S. C., Hoesli, M., and Peng, V. S. (2003), Do housing markets really matter? Journal of Housing Economics, 12 (1), pp. 12-28.

Brañas-Garza, P., Rodero Cosano, J. and Presley, J. R. (2002), The North-South divide and house price islands: the case of Córdoba (Spain), European Journal of Housing Policy, 2 (1), pp. 45-63.

Bring, J. (1994), How to Standardize Regression Coefficients, The American Statistician, 48 (3), pp. 209-213.

Brunsdon, C. F., Fotheringham, A. S., and Charlton, M. E. (1996), Geographically Weighted Regression: A Method for Exploring Spatial Nonstationarity, Geographical Analysis, 28 (4), pp. 281-298.

Craig, S. G. and Ng, P. T. (2001), Using Quantile Smoothing Splines to Identify Employment Subcenters in a Multicentric Urban Area, Journal of Urban Economics, 49 (1), pp . 100-120.

Darlington, R. (1990), Regression and Linear Models, McGraw-Hill, New York.

De Graaff, T., Florax, R. J. G. M., Nijkamp, P. and Reggiani, A. (2001), A general misspecification test for spatial regression model: dependence, heterogeneity, and nonlinearity, Journal of Regional Science, 41 (2), pp. 255-276.

Des Rosiers, F. and Thériault, M. (2008), Mass Appraisal, Hedonic Price Modelling and Urban Externalities: Understanding Property Value Shaping Process, in Kauko, T. and d'Amato, M. (eds.), Mass appraisal methods: an international perspective for property valuers, Blackwell Publishing Ltd., 332 p.

Dubin, R. A. (1998), Spatial Autocorrelation: A Primer, Journal of Housing Economics, 7 (4), pp. 304-327. 
Fujita, M. (1988), A Monopolistic Competition Model of Spatial Agglomeration: Differentiated Products Approach, Regional Science and Urban Economics, 18 (1), pp. 87-124.

Fujita, M. and Ogawa, H. (1982), Multiple Equilibria and Structural Transition of Nonmonocentric Urban Configurations, Regional Science and Urban Economics, 12 (2), pp. 161-196.

Fujita, M, Thisse, J.-F., and Zenou, Y. (1997), On the Endogenous Formation of Secondary Employment Centres in a City, Journal of Urban Economics, 41 (3), pp. 337-357.

Giuliano, G. and Small, K. A. (1991), Subcenters in the Los Angeles region, Regional Science and Urban Economics, 21 (2), pp. 163-182.

Grissom, T. V. and Diaz III, J. (1991), Real estate valuation: guide to investment strategies, John Wiley and Sons, New York.

Hansen, W. G. (1959), How Accessibility Shapes Land Use, Journal of the American Planning Association, 25 (2), pp. 73-76.

Harvey, J. and Jowsey, E. (2004), Urban Land Economics, sixth edition, Palgrave Macmillan, New York.

Kim, C. W., Phipps, T. T., and Anselin, L. (2003). Measure the benefits of air quality improvement: A spatial hedonic approach, Journal of Environmental Economics and Management, 45 (1), pp. 24-39.

King. G. (1986), How Not to Lie With Statistics: Avoiding Common Mistakes in Quantitative Political Science, American Journal of Political Science, 30 (3), pp. 666-687.

Krizek, K. J. (2005), Perspectives on Accessibility and Travel, In Miller, H. J., Levinson, D. and Krizek, K. J. Access to Destinations, Elsevier, pp. 109-130.

Kruskal, W. and Majors, P. (1989), Concepts of Relative Importance in Recent Scientific Literature, The American Statistician, 43 (1), pp. 2-6.

Kryvobokov, M. (2005) Formalisation of urban land value zoning with application of GIS-model (in Ukrainian), Candidate of Science thesis, Donetsk National Technical University, Donetsk.

LeSage, J. and Pace, R. K. (2009). Introduction to Spatial Econometrics, CRC Press, $354 \mathrm{p}$.

McDonald, J. F. (1987), The Identification of Urban Employment Subcenters, Journal of Urban Economics, 21 (2), pp . 242-258.

McDonald, J. F. (2008), Urban Transportation and Land Use, in Arnott, R. J. and McMillen, D. P. (eds.), A companion to urban economics, Blackwell Publishing Ltd., 574 p. 
McDonald J. F. and McMillen D. P. (1990), Employment subcenters and land values in a polycentric urban area: The case of Chicago, Environment and Planning A, 22 (12), pp. 1561-1574.

McDonald, J. F. and Prather, P. J. (1994), Suburban Employment Centres: The Case of Chicago, Urban Studies, 31 (2), pp. 201-218.

McMillen, D. P. (1996), One Hundred Fifty Years of Land Values in Chicago: A Nonparametric Approach, Journal of Urban Economics, 40 (1), pp. 100-124.

McMillen, D. P. (2001), Nonparametric Employment Subcenter Identification, Journal of Urban Economics, 50 (3), pp . 448-473.

McMillen, D. P. and McDonald, J. F. (1998), Suburban Subcenters and Employment Density in Metropolitan Chicago, Journal of Urban Economics, 43 (2), pp. 157180.

McMIllen, D. P. and Smith, S. C. (2003), The number of subcenters in large urban areas, Journal of Urban Economics, 53 (3), pp. 321-338.

McMillen, D. P. and Lester, T. W. (2003), Evolving subcenters: employment and population densities in Chicago, 1970-2020, Journal of Housing Economics, 12 (1), pp. 60-81.

Merlin, P. (1973), Méthodes quantitatives et espace urbain, Masson et Cie, Paris.

Miller, E. J. (2008), Accessibility: Some Definitions and Issues, mobil.TUM 2008 conference paper, Munich.

Morris, J. M., Dumble, P. L., and Wigan, M. R. (1979), Accessibility indicators for transport planning, Transportation Research Part A, 13 (2), pp. 91-109.

Munroe, D. K. (2007), Exploring the determinants of spatial pattern in residential land markets: amenities and disamenities in Charlotte, NC, USA, Environment and Planning B: Planning and Design, 34 (2): pp. 336-354.

Rosen, S. (1974), Hedonic prices and implicit markets: product differentiation in pure competition, Journal of Political Economy, 82, pp. 34-55.

Ross, J. M., Farmer, M. C., and Lipscomb, C. A. (2009). Inconsistency in Welfare Inferences from Distance Variables in Hedonic Regressions, Journal of Real Estate Finance and Economics, manuscript published online, 16 p.

Samaniego, H. and Moses, M. E. (2008), Cities as organisms: Allometric scaling of urban road networks, Journal of Transportation and Land Use, 1 (1), pp. 21-39.

Sanders, L. (2007), Agent Models in Urban Geography, in Phan, D. and Amblard, F. (eds.), Agent-based Modelling and Simulation in the Social and Human Sciences, The Bardwell Press, Oxford, 448 p. 
Seiler, M. J., Bond, M. T., and Seiler, V. L. (2001), The Impact of World Class Great Lakes Water Views on Residential Property Values, The Appraisal Journal, LXIX (3), pp. 287-295.

Sivitanidou, R. (1996), Do Office-Commercial Firms Value Access to Service Employment Centers? A Hedonic Value Analysis within Polycentric Los Angeles, Journal of Urban Economics, 40 (2), pp. 125-149.

Small, K. A. and Song, S. (1994), Population and Employment Densities: Structure and Change, Journal of Urban Economics, 36 (3), pp. 292-313.

So, H. M., Tse, R. Y. C., and Ganesan, S. (1997), Estimating the influence of transport on house prices: evidence from Hong Kong, Journal of Property Valuation and Investment, 15 (1), pp. 40-47.

Söderberg, B. and Janssen, C. (2001), Estimating Distance Gradients for Apartment Properties, Urban Studies, 38 (1), pp. 61-79.

Thériault, M., Des Rosiers, F., and Joerin, F. (2005), Modelling accessibility to urban services using fuzzy logic. A comparative analysis of two methods, Journal of Property Investment and Finance, 23 (1), pp. 22-54.

Watkins, C. (1998), Are new entrants to the residential property market informationally disadvantaged? Journal of Property Research, 15 (1), pp. 57-70.

Wilhelmsson, M. (2002), Spatial Models in Real Estate Economics, Housing, Theory and Society, 19 (2), pp. 92-101. 